\title{
Reconstructing the Christian Malford ecosystem in the Oxford Clay Formation (Callovian, Jurassic) of Wiltshire: exceptional preservation, taphonomy, burial and compaction
}

\author{
Malcolm B. Hart ${ }^{1}$, Kevin N. Page ${ }^{2}$, Gregory D. Price ${ }^{1}$, and Christopher W. Smart ${ }^{1}$ \\ ${ }^{1}$ School of Geography, Earth \& Environmental Sciences, \\ University of Plymouth, Drake Circus, Plymouth, PL4 8AA, UK \\ ${ }^{2}$ Thornedges, Long Barn, Crediton, Devon, EX17 4BR, UK \\ Correspondence: Malcolm B. Hart (mhart@plymouth.ac.uk)
}

Received: 8 February 2019 - Revised: 14 June 2019 - Accepted: 20 June 2019 - Published: 19 July 2019

\begin{abstract}
The Christian Malford lagerstätte in the Oxford Clay Formation of Wiltshire contains exceptionally well-preserved squid-like cephalopods, including Belemnotheutis antiquus (Pearce). Some of these fossils preserve muscle tissue, contents of ink sacks and other soft parts of the squid, including arms with hooks in situ and the head area with statoliths (ear bones) present in life position. The preservation of soft-tissue material is usually taken as an indication of anoxic or dysaerobic conditions on the sea floor and within the enclosing sediments. Interestingly, in the prepared residues of all these sediments there are both statoliths and arm hooks as well as abundant, species-rich, assemblages of both foraminifera and ostracods. Such occurrences appear to be incompatible with an interpretation of potential sea floor anoxia.

The mudstones of the Oxford Clay Formation may have been compacted by $70 \%-80 \%$ during de-watering and burial, and in such a fine-grained lithology samples collected for microfossil examination probably represent several thousand years and, therefore, a significant number of foraminiferal life cycles. Such samples (even if only 1-2 cm thick) could, potentially, include several oxic-anoxic cycles and, if coupled with compaction, generate the apparent coincidence of well-preserved, soft-bodied, cephalopods and diverse assemblages of benthic foraminifera.
\end{abstract}

1

\section{Introduction}

During the construction of the Great Western Railway west of Swindon in the 1840s "borrow pits" were excavated to provide material for the adjacent railway embankment. The mudstones of the Oxford Clay Formation (Callovian, Jurassic) yielded a large number of exceptionally well-preserved coleoid fossils (Pearce, 1841; Owen, 1844; Mantell, 1848), many of which have been redescribed by Donovan (1983), Page (1991), Page and Doyle (1991), and Donovan and Crane (1992). The majority of these specimens can be attributed to the Phaeinum Subchronozone (Athleta Chronozone, upper Callovian, Middle Jurassic), and many contain fossilized soft tissues, muscle fibres and the cell content of their ink sacks (Wilby et al., 2004, 2008; Hart et al., 2016a). As these mudstones also contain species-rich and abundant assemblages of microfossils that appear to indicate a normal, oxygenated sea floor this would look to be incompatible with soft-bodied preservation, which is often taken to indicate a lack of sea floor oxygen and rapid burial. This research explores this apparent contradiction and looks at the issue of taphonomy and the impacts of sediment compaction.

\section{Materials and methods}

The original excavations near Christian Malford and the subsequent discovery of comparable material near Ashton Keynes (Wilby et al., 2004) stimulated this reinvestigation 


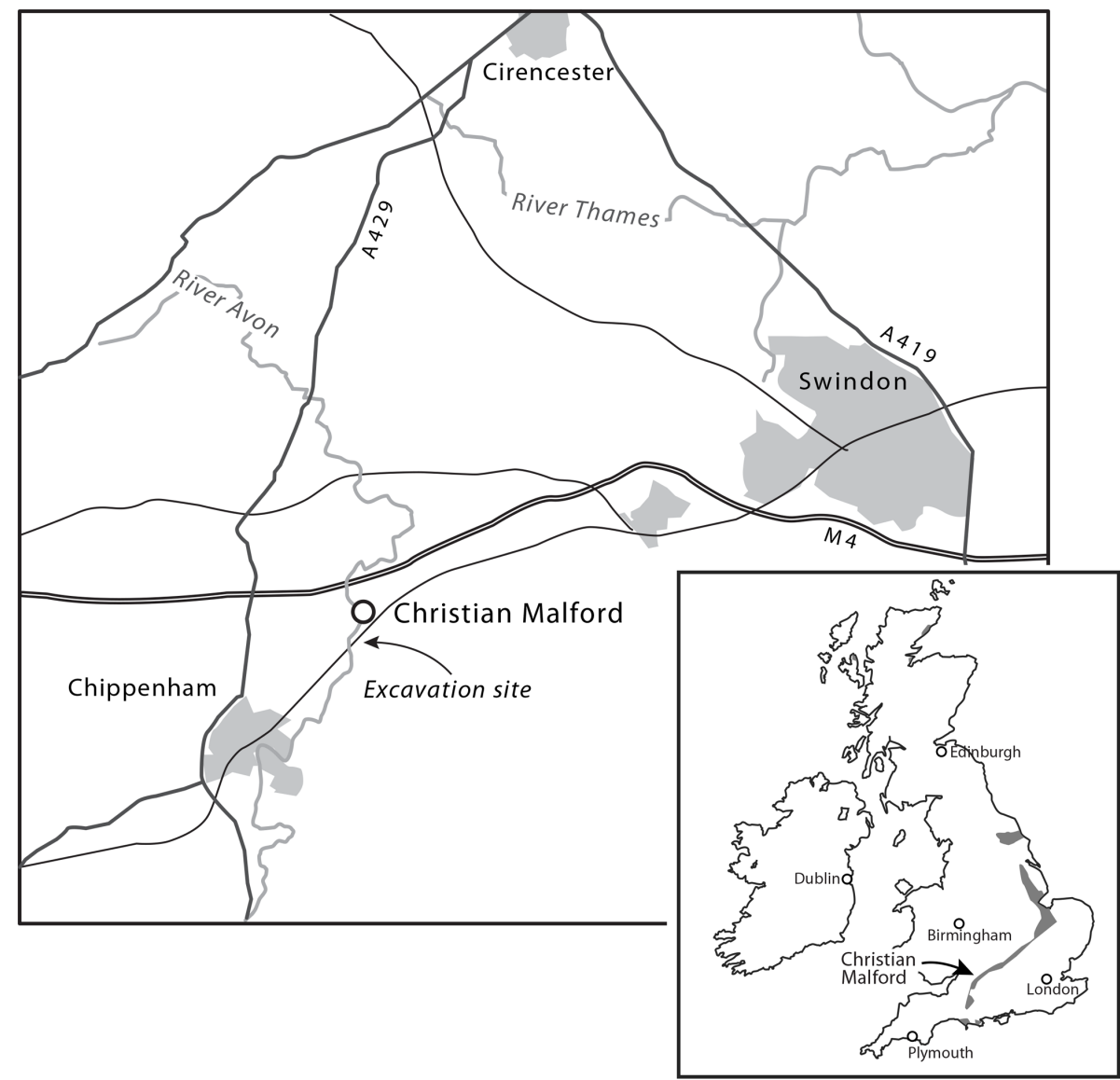

Figure 1. Locality map of Christian Malford (Wiltshire). The excavation site was immediately to the south of the railway line, as near to the original "borrow pits" as possible.

of the Christian Malford lagerstätte. In 2006 exploratory drilling was undertaken close to the railway line south of the village of Christian Malford in order to provide stratigraphical control for the subsequent excavations (Fig. 1). In October 2007, the full-scale excavation of a "pit" (surface area $32 \mathrm{~m}^{2}$ ) was undertaken but at $\sim 5 \mathrm{~m}$ depth became flooded, and fossil collecting was limited to $\sim 240 \mathrm{t}$ of spoil that had been arranged in approximate stratigraphical order around the pit prior to flooding. This material was, however, unsuitable for accurate micropalaeontological sampling and, from the sites drilled in 2006, Core 10 was selected for processing (Fig. 2). Core 10 was $\sim 5 \mathrm{~m}$ in length and preserved in six sections, all of which had been studied for macrofauna, resulting in parts of the core being fragmented and, in places, rendered unsuitable for very close sampling. Each section was approximately $62-108 \mathrm{~cm}$ in length and, after disregarding the top $10 \mathrm{~cm}$ of weathered mudstone and soil, 41 samples were collected. After removing the disturbed outer surface of the core, the samples were broken into small pieces, dried at $<40^{\circ} \mathrm{C}$ and weighed. Once dried the samples were processed using the Brasier (1980) white spirit method whereby each sample was soaked in the solvent which, after $\sim 4 \mathrm{~h}$, was then decanted and the sample immersed in deionized water for $<24 \mathrm{~h}$ (until disaggregated). Samples were washed on a $63 \mu \mathrm{m}$ sieve, filtered and dried in an oven at $<40{ }^{\circ} \mathrm{C}$. Samples were investigated in the $>500$, 500-250, 250-150 and 150-63 $\mu \mathrm{m}$ size fractions. All fractions were weighed prior to picking and/or counting. In the case of foraminifera a minimum of 250-300 individuals were counted in each size fraction, but the ostracods, otoliths, statoliths (Hart et al., 2009, 2013, 2015a, 2016a; Clarke, 2003; Clarke and Hart, 2018) and arm hooks (Hart et al., 2016a, 2019) were treated differently as, particularly in the case of statoliths, there are no counting protocols to follow. Weighing samples to determine foraminiferal numbers was undertaken but, as many of the specimens are in-filled with pyrite, any calculations based on these figures would probably be invalid. One major problem is that of adherent foraminifera, which are abundant in these Middle Jurassic mudstones. While many specimens of Bullopora, Vinelloidea and Nubeculinella have become detached, and could be counted alongside other foraminifera, many remain attached to shell fragments (e.g. Hart et al., 2009, Fig. 3), statoliths, otoliths and even other foraminifera. Specimens of Bullopora, once de- 


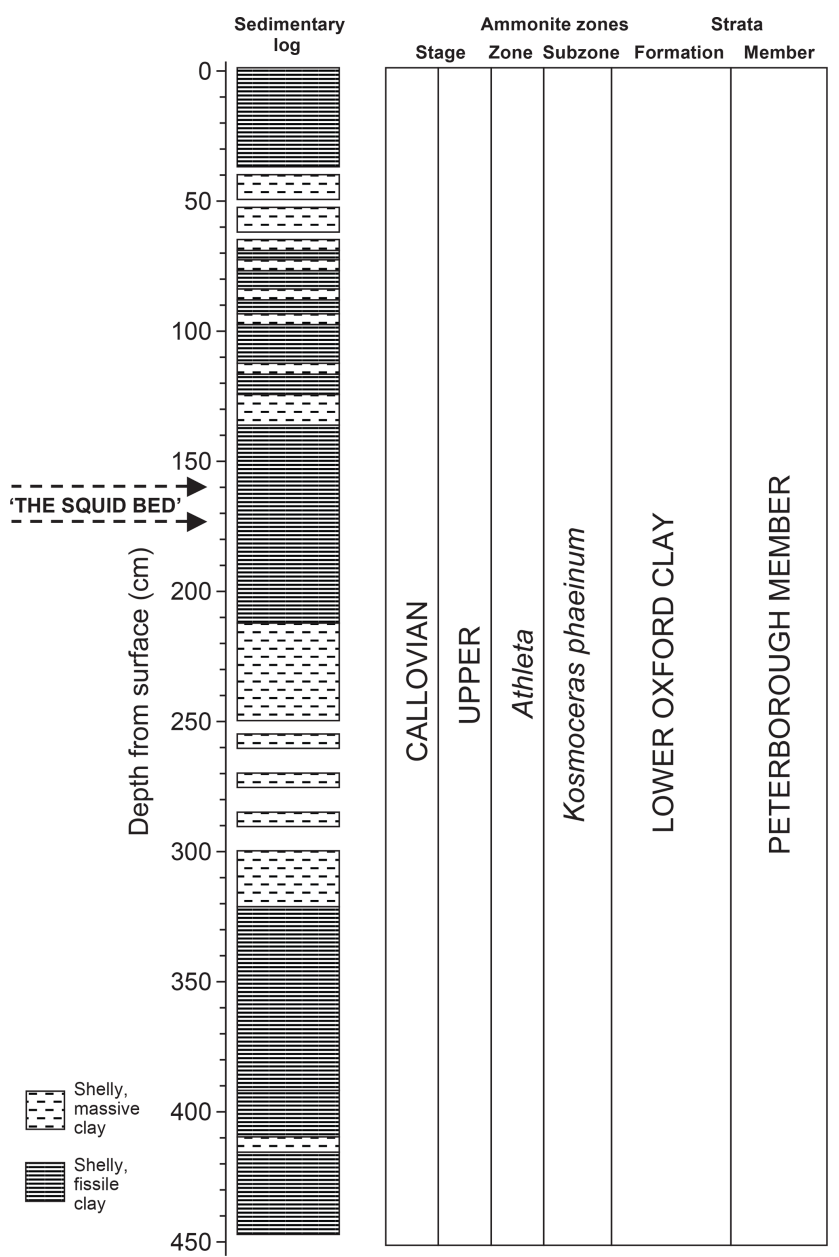

Figure 2. Core 10 sediment log, lithostratigraphy and biostratigraphy. Gaps in the log indicate no, or very reduced, recovery. Adapted from Hart et al. (2016a) with permission.

tached from the host surface, often break into one, two or several fragments, thereby making any counts almost meaningless.

While the foraminifera and ostracods are typical of Callovian-Oxfordian strata elsewhere in the UK and northern France (Cordey, 1963a, b; Coleman, 1974, 1982; Gordon, 1965, 1967; Barnard et al., 1981; Shipp, 1989; Morris and Coleman, 1989; Henderson, 1997; Page et al., 2003; Oxford et al., 2000, 2004; Wilkinson and Whatley, 2009), the statoliths (Clarke, 2003; Hart et al., 2015a, 2016a; Clarke and Hart, 2018) and arm hooks (Hart et al., 2016a, 2019) are both exceptional and relatively little-known. Formal taxonomy of the statoliths is still in progress, and in all cases open nomenclature has been used. At the present time the taxonomy and stratigraphical distribution of the ostracods has not been completed.

\section{Foraminifera}

The benthic foraminifera recorded in Core 10 are dominated by calcareous taxa, with relatively few agglutinated species (Fig. 3). The absolute abundance of benthic foraminifera, when measured as number per gram is relatively low (Hart et al., 2016a, fig. 8) even though the assemblages are quite diverse and appear abundant. The heterogeneity $(\mathrm{H})$ fluctuates throughout the succession (average 0.5-1.0) while the dominance (as percentage) is highly variable (Hart et al., 2016a, fig. 9). When the assemblage is subdivided into agglutinated, aragonitic and calcitic taxa (Fig. 4), a number of patterns emerge. As the agglutinated foraminifera are generally rare, the graphs of aragonitic and calcitic taxa are, quite clearly, showing the same variation. There are only two samples in which there was a very slight increase in the agglutinated taxa ( $\sim 205$ and $\sim 365 \mathrm{~cm}$ core depth). There appear to be no differences in sediment type at these levels or evidence of any hiatus.

If the distribution of aragonitic taxa is subdivided into the component species, then the dominance of Epistomina regularis becomes apparent (Fig. 5). The graph in Fig. 5 shows a number of oscillations with "peaks" at 60-80, 140-150, 260$280, \sim 375 \mathrm{~cm}$ and (perhaps) $\sim 425 \mathrm{~cm}$. Oxford et al. (2004) have reported a similar variability in the distribution of epistominids in the Oxfordian strata of the Dorset coast east of Weymouth and suggested that this may be picking up the maximum flooding "zones" of para-sequences. The distributions of both statoliths (Hart et al., 2016a, fig. 4) and otoliths (Hart et al., 2016a, fig. 5) show patterns with some features in parallel with the distribution of the epistominids though the reasons for this are not obvious as both coleoids and teleost fish are nektonic, rather than benthic, organisms.

The "flood" of E. stellicostata is significant as, in the British Geological Survey pit, large slabs of slightly fissile mudstone covered in foraminifera were also found (Hart et al., 2016a, fig. 12). Some of these epistominids contain the chitinous inner linings of chambers (Wilby et al., 2004, textfig. 2) and clearly indicate an unusual degree of preservation, possibly suggestive of dysaerobic or even anoxic conditions on the sea floor or just below the water-sediment interface. This may be the only evidence of a short-term event recorded by our foraminiferal investigation. Winnowing does not seem to be an option, as a mechanism to concentrate only one species of epistominid is impossible to envisage.

\section{Taphonomy}

Throughout the samples from the excavations and the cores, many of the macrofossils are compressed, and this includes both the ammonites (e.g. Kosmoceras phaeinum) and the coleoid phragmacones. This is normal in Jurassic mudstones and indicates a certain degree of post-depositional dewatering and compaction. The most conspicuous macrofossils are the bivalves Bositra and Meleagrinella and the gas- 


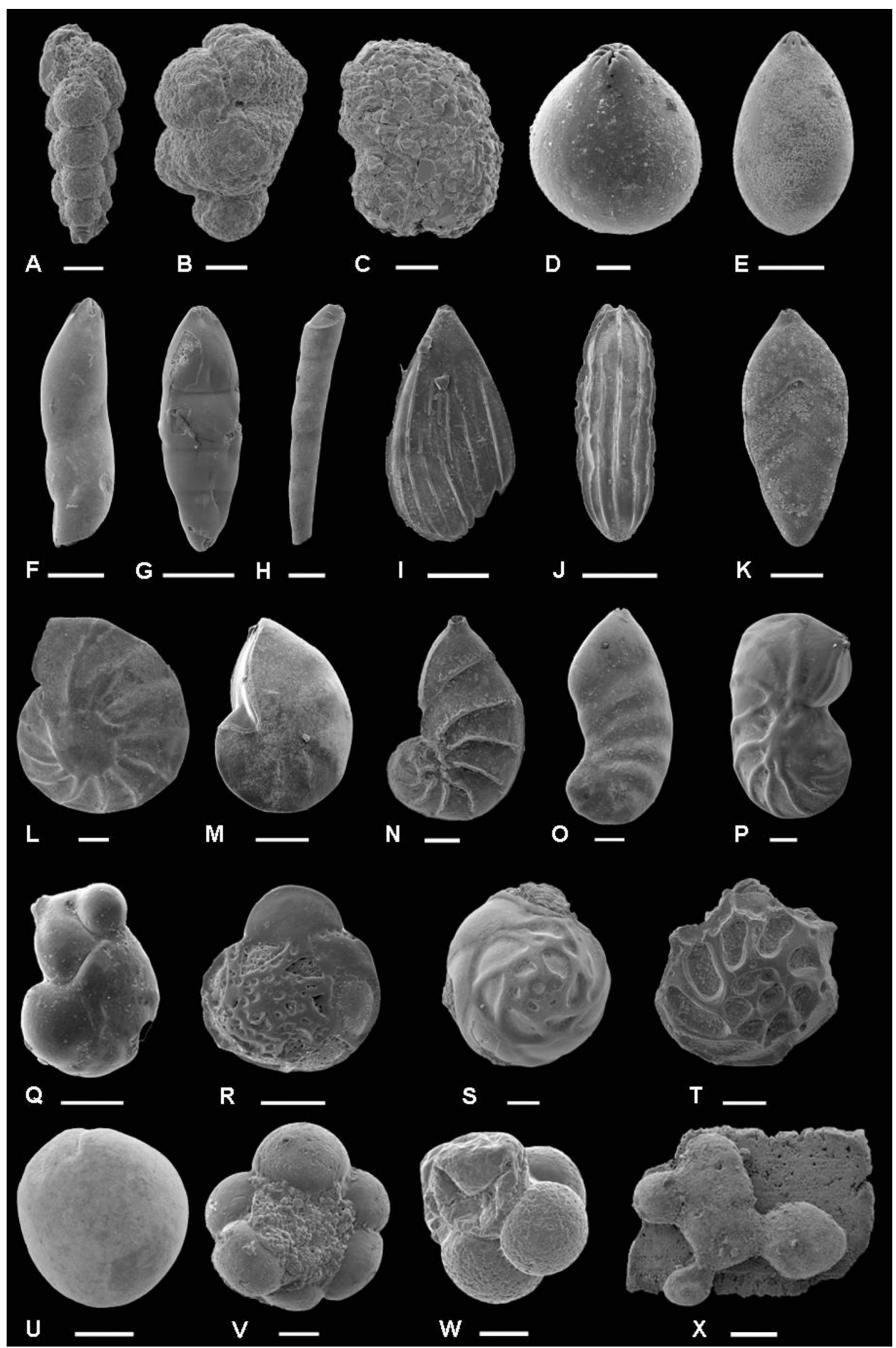

Figure 3. Illustration of some of the foraminifera recovered in the samples from Core 10: (a) Verneuilinoides tryphera (scale bar 50 $\mu$ m); (b) Verneuilinoides sp. 2 Morris and Coleman, 1989 (scale bar $50 \mu \mathrm{m}$ ); (c) Trochammina sp. (scale bar $100 \mu \mathrm{m}$ ); (d) Oolina sp. (scale bar $20 \mu \mathrm{m})$; (e) Oolina sp. (scale bar $100 \mu \mathrm{m})$; (f) Eoguttulina liassica (scale bar $100 \mu \mathrm{m})$; (g) Frondicularia irregularis (scale bar 100 $\mu \mathrm{m})$; (h) Dentalina pseudocommunis (scale bar $100 \mu \mathrm{m})$; (i) Citharina flabellata (scale bar $100 \mu \mathrm{m})$; (j) Nodosaria hortensis (scale bar $100 \mu \mathrm{m})$; (k) Frondicularia franconica (scale bar $100 \mu \mathrm{m}$ ); (l) Lenticulina muensteri (scale bar $100 \mu \mathrm{m})$; (m) L. muensteri with no umbilical boss (scale bar $100 \mu \mathrm{m}$ ); (n) L. muensteri showing uncoiling (scale bar $100 \mu \mathrm{m})$; (o) Lenticulina sp., showing distinct uncoiling and thickened sutures (scale bar $100 \mu \mathrm{m})$; (p) L. muensteri, showing test deformation (scale bar $100 \mu \mathrm{m}$ ); (q) Lenticulina sp., showing chamber deformation and, what appears to be an additional chamber (scale bar $100 \mu \mathrm{m})$; (r, s) Epistomina regularis (scale bar $100 \mu \mathrm{m})$; (t) Epistomina stellicostata Bielecka and Pozaryski (scale bar $100 \mu \mathrm{m})$; (u) Reinholdella lutzei (scale bar $100 \mu \mathrm{m})$; (v, w) Conoglobigerina sp., an example of a pyrite steinkern of a planktic foraminiferid (scale bar $50 \mu \mathrm{m}$ ); (x) Bullopora sp. adherent on shell fragment (scale bar $200 \mu \mathrm{m})$. Reproduced from Hart et al. (2016a) with permission. 


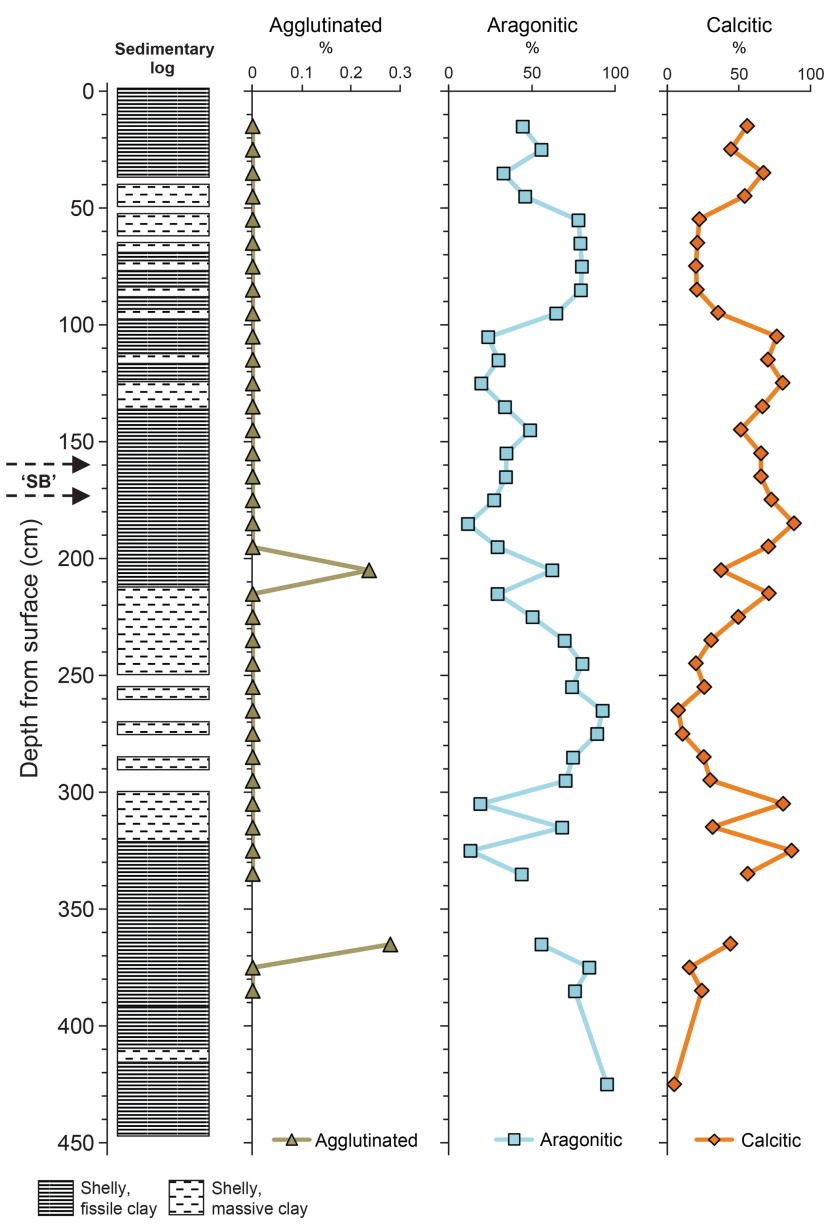

Figure 4. Distribution of foraminifera (agglutinated, aragonitic, calcitic). Adapted from Hart et al. (2016a) with permission.

tropod Dicroloma. Though often appearing complete, when samples were processed, cracks caused by compaction often caused specimens to collapse. Wilby et al. (2008) also recorded levels in which there was a conspicuous absence of benthos and interpreted this as indicative of inhospitable conditions on the sea floor. This observation was also supported by the frequent occurrence of microscopic juvenile bivalves (spat) that did not grow to maturity. As these spat have been found in microfossil residues containing foraminifera and ostracods, their failure to develop may be associated with other environmental issues. There is also evidence of soft tissue preservation which is often used as an indicator of dysaerobic or even anoxic conditions on the sea floor (Wilby et al., 2004, 2008). However, all our samples contain both foraminifera and ostracods, which is suggestive of oxygenated conditions on the sea floor. The question is, therefore, how one resolves this apparent disagreement in the interpretation of the sea floor conditions that generate both abundant and diverse assemblages of foraminifera and a world-famous lagerstätte for the soft-bodied preservation of coleoid cephalopods (e.g. Belemnotheutis).

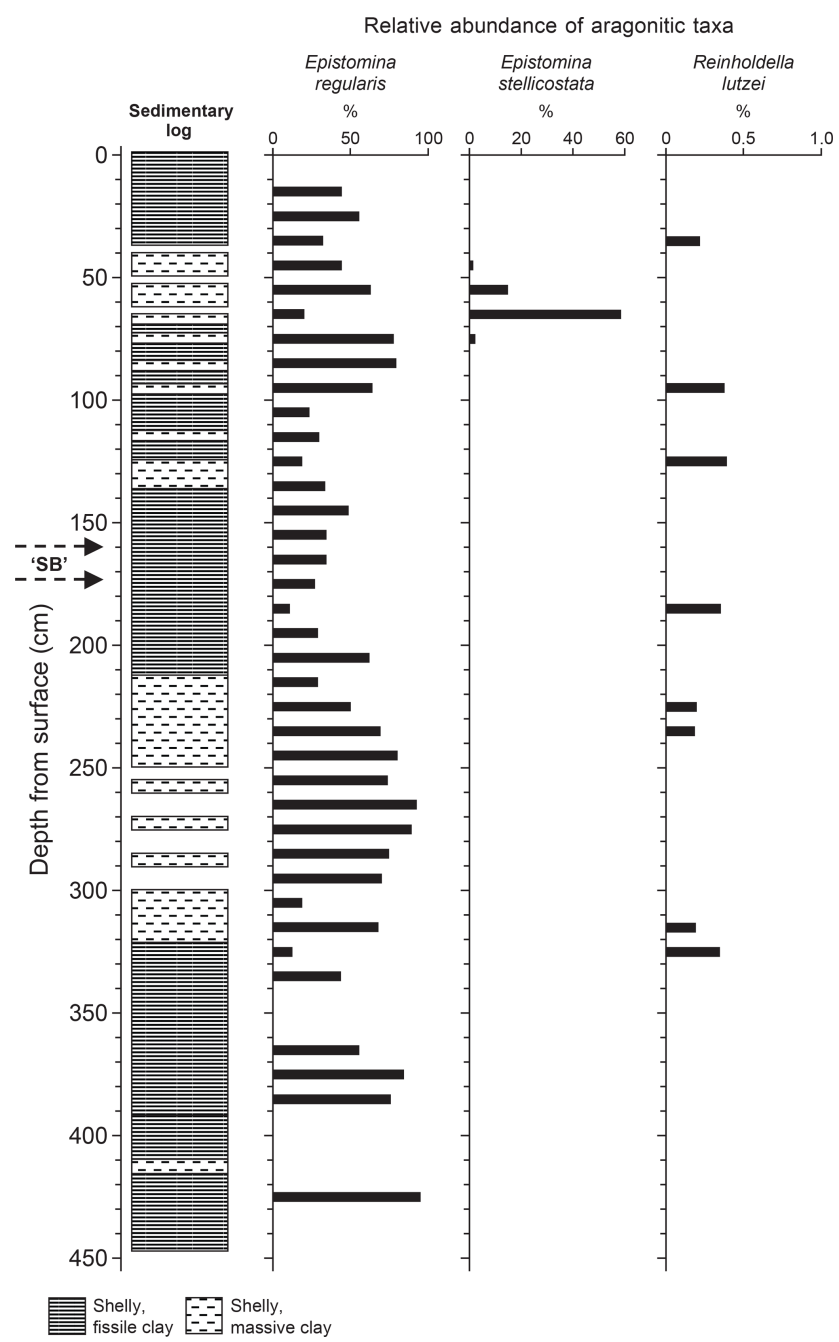

Figure 5. Distribution of epistominids in Core 10, showing the "flood" of Epistomina stellicostata at $60 \mathrm{~cm}$ downhole, and the potential cyclicity in the recorded numbers of E. regularis. Adapted from Hart et al. (2016a) with permission

\subsection{Modern environments}

Modern samples from a range of locations in south-west England have been investigated for foraminifera, including Plymouth Sound (Castignetti, 1997), offshore Plymouth (Hart et al., 2016b), Fowey Estuary (Hart et al., 2014) and Fal Estuary (Olugbode et al., 2005; Hart et al., 2015b, 2017). Samples from all these locations were fixed with ethanol and, during processing, were stained with rose bengal in order to identify the individuals that were living at the time of collection. In all samples it was found that living foraminifera are relatively rare, often comprising only $\sim 1 \%$ of the total assemblage recovered. This indicates that most sea floor samples contain large numbers of dead foraminifera, probably representing several seasonal cycles, as well as any specimens brought in by wave or storm activity (Hart et al., 2016b). Muddy samples, which often contain more organic 
material, usually contain a more abundant and diverse assemblage compared to sediments with a higher sand or silt component (e.g. Plymouth Sound; see Oxford et al., 2004, fig. 7). The mud-rich samples from Stations L4 and E1 of the Western Channel Observatory (Smyth et al., 2015; Hart et al., 2016b) from water depths of $\sim 50$ and $\sim 75 \mathrm{~m}$ respectively are the closest to the environments represented by the Callovian mudstones of Christian Malford. Samples collected at these locations and the nearby Hillsand Station (Hart et al., 2016b, fig. 1) all contain $<1 \%$ living foraminifera even when collected in early June. The greater part of the assemblage must represent life cycles from the previous years as well as transported individuals. Samples from box cores at $<50 \mathrm{~cm}$ subsurface contain comparable assemblages of foraminifera to the surface, but the clays are, even at this depth, beginning to consolidate with reduced water content.

\subsection{Jurassic mudstones}

During compaction (Sarda and Yang, 1998; Yang and Aplin, 2010), as a result of burial and de-watering, the clay-rich sediments will compact more than those with a silt or sand component, perhaps by up to $75 \%-80 \%$ (Fig. 6). With rising levels of compaction, the clay-rich samples become less porous and permeable, eventually becoming an aquiclude. This suppresses water movement and reduces the possibility of postdepositional dissolution. Oxygen levels would also become reduced, and this would enhance the preservation of aragonitic microfossils such as epistominid foraminifera, otoliths and statoliths. The preservation of organic material within the sediment would also be enhanced, leading to the preservation (Wilby et al., 2004) of soft-bodied fossils that had for various reasons - survived on, and just below, the sea floor. The original sea floor assemblage of several life cycles of foraminifera will be enhanced by the reduction in sediment thickness, and any micropalaeontological work, even if based on samples of only $1-2 \mathrm{~cm}$ vertical thickness, would clearly represent an unknown number of life (i.e. annual?) cycles.

Horizons within these mudstones that may have been dysaerobic, or even anoxic, for a short period of time could easily be "lost" within samples that still yield a "normal" assemblage of foraminifera and other microfossils. If the dysaerobic-anoxic horizons were temporary, then the development of a characteristic agglutinated assemblage (Hart, 2018) may not have had the time to develop or, being mixed with a normal assemblage from the immediately adjacent sediments, would not be detectable after processing.

An average sample thickness of $2-5 \mathrm{~cm}$ is, therefore, incapable of resolving the foraminiferal assemblage to the accuracy required to detect temporary anoxia and the preservation of a coleoid fossil with in situ soft parts. Even sampling to a resolution of 1-2 cm would be incapable of resolving the assemblage into seasonal cycles within a mudstone succession compacted by $75 \%-80 \%$ (or even less). This could mean

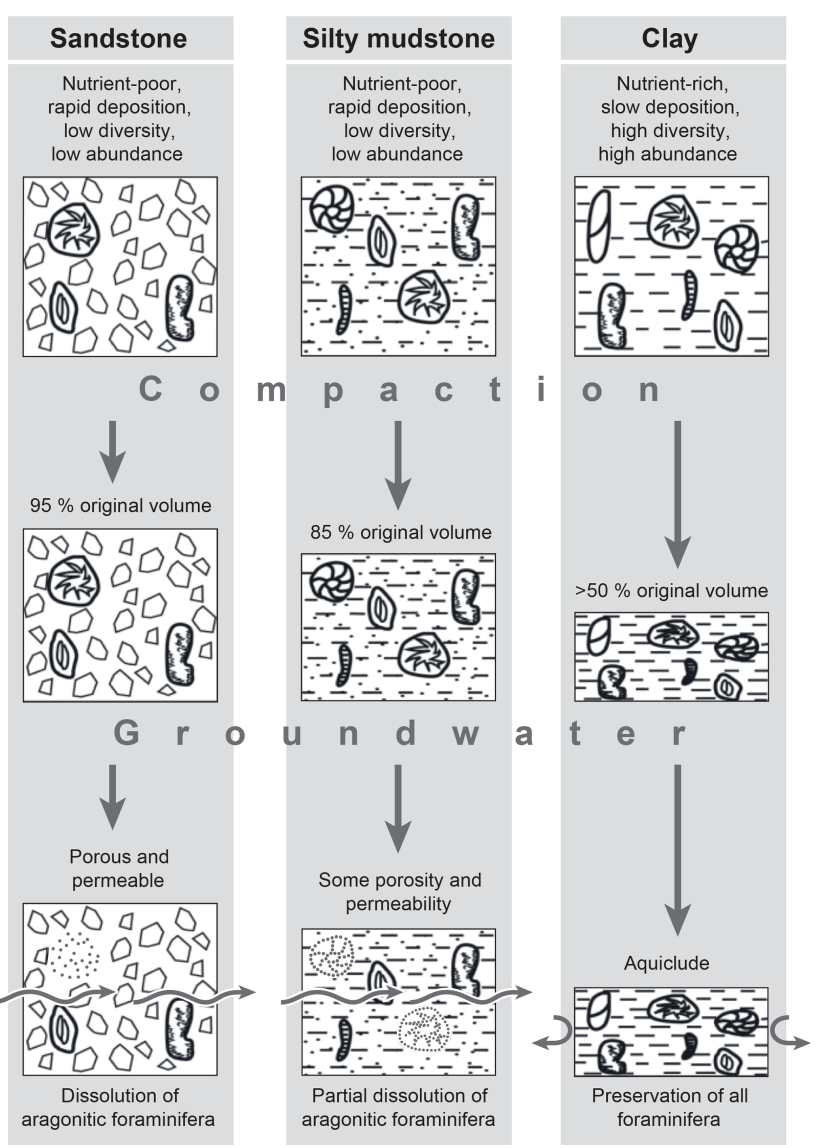

Figure 6. Model for the preservation of the microfossil assemblage and compaction of sediments from the Oxford Clay Formation.

that temporary anoxia, capable of soft-bodied preservation, is masked by an apparently normal, benthic foraminiferal assemblage.

One possible test of this concept would be to sample a thin $(0.2-0.5 \mathrm{~cm})$ horizon exactly contiguous with an exceptionally preserved coleoid as well as the sediment immediately below and above the fossil. This might detect differences, although the resolution of such fine sampling may not be enough. This would probably have to be done in the field, adjacent to a fossil, as few museums would entertain sampling their valuable specimens in such a way even if it were physically possible.

\section{Summary}

In the Oxford Clay Formation (Callovian-Oxfordian) of southern England there is a species-rich, abundant assemblage of foraminifera and ostracods, though the latter have not been fully investigated. These mudstones are highly compacted as many macrofossils (ammonites, coleoid phragmacones, etc.) are completely flattened. The presence of wellpreserved members of the superfamily Ceratobuliminidae 
(sensu Loeblich and Tappan, 1987) is indicative of the assemblage not being impacted by dissolution caused by migratory fluids and groundwater. As the sedimentation rate was probably quite low, rapid burial was probably not a contributory factor in the preservation debate.

From the investigation of modern assemblages it is known that most sea floor samples contain the record of several life cycles as well as the presence of transported and reworked foraminifera. If the mudstones have been compacted by $>70 \%$, then the average core sample of $2-5 \mathrm{~cm}$ thickness is incapable of the identification of the temporary dysaerobic or anoxic conditions required for the preservation of softbodied macrofossils such as coleoids. This rare occurrence of pavements of epistominid foraminifera, some containing the original organic chamber linings, points to such levels of temporary anoxia. This interpretation may help to resolve the current conflict between the presence of soft-bodied fossils (indicating potentially anoxic conditions) and species-rich assemblages of foraminifera (indicating oxic conditions).
Data availability. All samples and picked slides are in the collections of the School of Geography, Earth \& Environmental Sciences, University of Plymouth. 


\section{Appendix A: Taxonomic notes on foraminifera}

The species mentioned in the text are well known from Jurassic strata in the UK and a full taxonomy is not presented. The species are listed in alphabetical (not taxonomic) order.

Bullopora rostrata Quenstedt, 1857: p. 580, pl. 73, fig. 28.

Citharina flabellata (Gümbel, 1862) = Marginulina flabellata Gümbel, 1862: p. 223, pl. 3, fig. 24.

Compactogerina stellapolaris (Grigelis, 1977) $=$ Globuligerina stellapolaris Grigelis, 1977: p. 927, textfig. 1a-c.

Dentalina pseudocommunis Franke, 1936: p. 30, pl. 2, fig. 20.

Eoguttulina liassica $($ Strickland, 1846$)=$ Polymorphina liassica Strickland, 1846: p. 31, text-fig. b.

Epistomina regularis Terquem, 1883: p. 379, pl. 44, figs. 1-3.

Epistomina stellicostata Bielecka and Pozaryski, 1954: p. 71 , pl. 12, fig. $60 \mathrm{a}-\mathrm{c}$.
Frondicularia franconica Gümbel, 1862: p. 219, pl. 3, fig. 13a-c.

Frondicularia irregularis Terquem, 1870: p. 125, pl. 4, fig. 12a, b.

Lenticulina muensteri (Roemer, 1839) = Robulina mиensteri Roemer, 1839: p. 48, pl. 20, fig. 29.

Neogloboquadrina pachyderma (Ehrenberg, 1861) = Globigerina pachyderma $($ Ehrenberg $)=$ Aristerospina pachyderma Ehrenberg, 1861: p. 276-277, 303, but figured by Ehrenberg, 1873 (for 1872), pl. 1, fig. 4 .

Nodosaria hortensis Terquem, 1866: p. 476, pl. 19, fig. 13.

Reinholdella lutzei Barnard, Shipp, and Cordey, 1981: p. 432 , pl. 4, figs. 3,7 .

Verneuilinoides tryphera Loeblich and Tappan, 1950: p. 42, pl. 11, fig. 16a, b. 
Author contributions. Fieldwork was carried out by MBH, KNP and GDP, stratigraphy by KNP, micropalaeontology and SEM imaging by MBH and CWS, and all were involved in discussion and editorial work.

Competing interests. The authors declare that they have no conflict of interest.

Acknowledgements. The authors wish to thank the British Geological Survey (especially Phil Wilby) for access to the material from Christian Malford and the two reviewers who prompted improvements to the original manuscript.

Review statement. This paper was edited by Thomas M. Cronin and reviewed by Laura Gemery and one anonymous referee.

\section{References}

Barnard, T., Cordey, W. G., and Shipp, D. J.: Foraminifera from the Oxford Clay (Callovian-Oxfordian) of England, Revista Español de Micropaleontologia, 13, 383-462, 1981.

Brasier, M. D.: Microfossils, George Allen \& Unwin, London, 193 pp., 1980.

Castignetti, P.: Population dynamics and facies association of recent foraminifera from a nearshore marginal marine environment: Plymouth Sound, unpublished PhD thesis, Plymouth University, 1997.

Clarke, M. R.: Potential of statoliths for interpreting coleoid evolution. A brief review, Berliner Paläobiologische Abhandlungen, 3, 37-47, 2003.

Clarke, M. R. and Hart, M. B.: Part M, Chapter 11: Statoliths and coleoid evolution, Treatise Online, 102, 1-23, 2018.

Coleman, B. E.: Foraminifera of the Oxford Clay and the Kellaways Beds. Appendix 3. The geology of the new town of Milton Keynes: Report, Institute of Geological Sciences, No. 74/1b, 1974.

Coleman, B. E.: Lower and Middle Jurassic foraminifera from the Winterbourne Kingston Borehole, Dorset, in: The Winterbourne Kingston Borehole, Dorset, England, edited by: Rhys, G. H., Lott, G. K., and Calver, M. A., Report, Institute of Geological Sciences, No. 81/3, 82-88, 1982.

Cordey, W. G.: The genera Brotzenia Hofker 1954, and Voorthuysenia Hofker 1954 and Hofker's classification of the Epistomariidae, Palaeontology, 6, 653-657, 1963a.

Cordey, W. G.: Oxford Clay foraminifera from England (Dorset Northamptonshire) and Scotland, unpublished $\mathrm{PhD}$ thesis, University College, London University, 1963b.

Donovan, D. T.: Mastigophora Owen 1856: a little known genus of Jurassic coleoids. 1983, Neue Jahrbuch für Geologie und Paläontologie, Abhandlungen, 165, 484-495, 1983.

Donovan, D. T. and Crane, M. D.: The type material of the Jurassic cephalopod Belemnotheutis, Palaeontology, 35, 273-296, 1992.

Gordon, W. A.: Foraminifera from the Corallian Beds, Upper Jurassic of Dorset, England, J. Paleontol., 39, 838-863, 1965.
Gordon, W. A.: Foraminifera from the Callovian (Middle Jurassic) of Brora, Scotland, Micropaleontology, 13, 445-464, 1967.

Hart, M. B.: The "Black Band": local expression of a global event, P. Yorks. Geol. Soc., 62, 217-226, https://doi.org/10.1144/pygs2017-007, 2018.

Hart, M. B., De Jonghe, A., Grimes, S. T., Metcalfe, B., Price, G. D., and Teece, C.: Microfaunal analysis of the Wattonensis Beds (Upper Bathonian) of South Dorset, Geoscience in South-West England, 12, 134-139, 2009.

Hart, M. B., De Jonghe, A., Rundle, A. J., and Smart, C. W.: Statoliths: neglected microfossils, J. Micropalaeontol., 32, 219-220, https://doi.org/10.1144/jmpaleo2012-016, 2013.

Hart, M. B., Stubbles, S. J., Smart, C. W., Fisher, J. K., Hoddinott, C., Marshall-Penn, I., and Yeo, A.: Foraminifera from the Fowey Estuary, Cornwall, Geoscience in South-West England, 13, 304315, 2014.

Hart, M. B., Clarke, M. R., De Jonghe, A., Price, G. D., Page, K. N., and Smart, C. W.: Statoliths from the Jurassic succession of south-west England, United Kingdom, Swiss Journal of Paleontology, 134, 199-205, 2015a.

Hart, M. B., Cartwright, K., Fisk, B., Smart, C. W., Consolaro, C., and Hall-Spencer, J. M.: Foraminifera of the Fal Estuary (Cornwall), including taxa associated with Maerl Beds, Geoscience in South-West England, 13, 483-490, 2015b.

Hart, M. B., De Jonghe, A., Page, K. N., Price, G. D., and Smart, C. W.: Exceptional accumulations of statoliths in association with the Christian Malford Lagerstätte (Callovian, Jurassic) in Wiltshire, United Kingdom, Palaios, 31, 203-220, 2016 a.

Hart, M. B., Molina, G. S., Smart, C. W., and Widdicombe, C. E.: The Western Channel Observatory: benthic foraminifera in the plankton following storms, Geoscience in South-West England, 14, 39-45, 2016 b.

Hart, M. B., Molina, G. S., Smart, C. W., and Hall-Spencer, J. M.: The distribution of foraminifera in the Fal Estuary (Cornwall), Geoscience in South-West England, 14, 129-139, 2017.

Hart, M. B., Hughes, Z., Page, K. N., Price, G. D., and Smart, C. W.: Arm hooks of coleoid cephalopods from the Jurassic succession of the Wessex Basin, Southern England, P. Geologists' Assoc., 130, 326-338, https://doi.org/10.1016/j.pgeola.2018.02.008, 2019.

Henderson, A. S.: The palaeoecology and biostratigraphy of the foraminifera from the Oxfordian of North Dorset, unpublished PhD thesis, University of Plymouth, 1997.

Loeblich, A. R. and Tappan, H.: Foraminiferal genera and their classification, Van Nostrand Reinhold, New York, 1987.

Mantell, G. A.: Observations on some belemnites and other fossil remains of Cephalopoda, discovered by Mr Reginald Neville Mantell in the Oxford Clay near Trowbridge, in Wiltshire, Philos. T. R. Soc., 138, 171-182, 1848.

Morris, P. H. and Coleman, B. E.: The Aalenian to Callovian (Middle Jurassic), in: Stratigraphical Atlas of Fossil Foraminifera, edited by: Jenkins, D. G. and Murray, J. W., Ellis Horwood Ltd, Chichester (on behalf of The British Micropalaeoneological Society), 189-236, 1989.

Olugbode, O. I., Hart, M. B., and Stubbles, S. J.: Foraminifera from Restronguet Creek: monitoring recovery from the Wheal Jane pollution incident, Geoscience in South-West England, 11, 8292, 2005 . 
Owen, R. A.: A description of certain belemnites, preserved, with a great proportion of their soft parts, in the Oxford Clay at Christian Malford, Wilts, Philos. T. R. Soc., 125, 65-85, 1844.

Oxford, M. J., Hart, M. B., and Watkinson, M. P.: Micropalaeontological investigations of the Oxford Clay - Corallian succession of the Dorset Coast, Geoscience in South-West England, 10, 9$13,2000$.

Oxford, M. J., Hart, M. B., and Watkinson, M. P.: Foraminiferal characterisation of mid-Upper Jurassic sequences in the Wessex Basin (United Kingdom), Riv. Ital. Paleontol. S., 110, 209-218, 2004.

Page, K. N.: Ammonites, in: Fossils of the Oxford Clay, edited by: Martill, D. M. and Hudson, J. D., Palaeontological Association, Field Guides to Fossils No. 4, The Palaeontological Association, London, 86-143, 1991.

Page, K. N. and Doyle, P.: Other cephalopods, in: Fossils of the Oxford Clay, edited by: Martill, D. M. and Hudson, J. D., Palaeontological Association, Field Guides to Fossils, No. 4. The Palaeontological Association, London, 144-162, 1991.

Page, K. N., Hart, M. B., and Oxford, M. J.: The search for a Global Stratotype section and Point (GSSP) for the base of the Oxfordian Stage, Geoscience in South-West England, 10, 435-441, 2003.

Pearce, J. C.: On the mouths of ammonites and on fossils contained in laminated beds of the Oxford Clay, discovered in cutting the Great Western Railway, near Christian Malford in Wiltshire, Proceedings of the Geological Society, London, 3, 592-594, 1841.
Sarda, J.-P. and Yang, Y.: Compaction-driven evolution of porosity and permeability in natural mudstones: an experimental study, J. Geophys. Res., 103, 651-661, 1998.

Shipp, D. J.: The Oxfordian to Portlandian, in: Stratigraphical Atlas of Fossil Foraminifera, edited by: Jenkins, D. G. and Murray, J. W., Ellis Horwood Ltd., Cichester (on behalf of The British Micropalaeoneological Society), 237-272, 1989.

Smyth, T., Atkinson, A., Widdicombe, S., Frost, M., Allen, I., Fishwick, J., Queiros, A., Sims, D., and Barange, M.: The Western Channel Observatory, Prog. Oceanogr., 137, 335-341, 2015.

Wilby, P. R., Hudson, J. D., Clements, R. G., and Hollingworth, N. T. J.: Taphonomy and origin of an accumulate of soft-bodied cephalopods in the Oxford Clay Formation (Jurassic, England), Palaeontology, 47, 1159-1180, 2004.

Wilby, P. R., Duff, K., Page, K., and Martin, S.: Preserving the unpreservable: a lost world rediscovered at Christian Malford, UK, Geology Today, 24, 95-98, 2008.

Wilkinson, I. P. and Whatley, R. C.: Upper Jurassic (CallovianPortlandian), in: Ostracods in British Stratigraphy, edited by: Whittaker, J. E. and Hart, M. B., Micropalaeontological Society, Special Publication, Geological Society, London, 241-287, 2009.

Yang, Y. and Aplin, A. C.: A permeability-porosity relationship for mudstones, Mar. Petrol. Geol., 27, 1692-1697, 2010. 